\title{
A Comparative Study of Transactional Styles of Higher Education Teachers
}

Effulgence

Vol. 16 No. 1 (Special Issue 2)

January - June, 2018 Rukmini Devi Institute of Advanced Studies

E-mail : effulgence@rdias.ac.in, Website : www.rdias.ac.in

http://effulgence.rdias.ac.in/user/default.aspx

https://dx.doi.org/10.33601/effulgence.rdias/v16/iSpl2/2018/121-131

\section{Dr. Poonam Khurana ${ }^{1}$}

\begin{abstract}
Purpose:

Transactional Analysis (TA) is an illustration of relationship between personality and behavior and an organized tool for personal development and personal effectiveness. When two persons interact with each other, a social exchange of ideas and behavior takes place. Analysis of these exchanges or transactions is called transactional analysis. TA teaches the phenomenon of life script and explains how our present life patterns originated in childhood. It provides a theory of effective communication. Eric Berne the founder of transactional analysis, made complex interpersonal transactions understandable when he explained that the human personality is made up of three "ego states". Each ego state is an entire system of thoughts, feelings, and behaviors from which we transact with one another. The present study has been intended to find out whether there is any difference between the Transactional Analysis Styles of faculty teaching in higher education Institutes with in relation to various demographical factors.
\end{abstract}

\section{Objectives of Study}

(1) To design the Transactional Analysis profiles offaculty members.

(2) To study whether there is any difference between the Transactional Analysis Styles of faculty members in relation to the following:

a. Gender

b. Age

c. Qualification

d. Organization

e. Position

f. Work Experience

(3) To develop a model of Transactional Analysis Styles for the faculty members.

Design/ Methodology/Approach: In the present study, sample consisted of faculty members working for colleges like Management and Engineering, faculty members (Male \& Female) working in different work positions with variety of expertise and educational qualification are selected for the study. The sample size for the study is 150 faculty. The faculty members are of minimum 25 years of age; who are at least Post Graduates and have at least 0-5 years of work experience.

\section{Associate Professor- Vivekananda institute of Professional Studies}


Instrument used: The inventory which has been used for the research is.Transactional Styles Inventory-Teachers (TSI- Te). It had been developed by Udai Pareek(2003). Test and Re-test method was carried out to establishing reliability of the inventory. The reliability was 0.81.Styles include:

$$
\begin{aligned}
& \text { - Nurturing } \\
& \text { - Regulating } \\
& \text { - Task-Oriented } \\
& \text { - Confronting } \\
& \text { - Adaptive } \\
& \text { - Creative }
\end{aligned}
$$

Originality/Value: The researcher has created an original database with the help of 150 teaching fraternity in higher education institutes of Delhi, NCR. The researcher has conducted an original study that has attained a workable and truthful conclusion. $T$ test and Anova has been used as statistical analysis techniques for the variables i.e. Nurturing, Regulating, Task- Oriented, Confronting, Adaptive and Creative styles in relation the demographic variables under study to reach to the conclusion and inferences.

\section{Majorfindings:}

- Male faculty members are more creative in teaching than female faculty members.

- Teachers in the age group (45 years and above) are significantly higher on 'Adaptive "style as compared to Teachers in the age group (25-35 yrs).

- Teachers with doctorate seem to be more nurturing as compared to teachers with only PG qualification.

- The faculty at the level of Assistant professors are more confronting as compared to professors in their transactional styles.

Keywords: Transactional styles, teachers, higher education.

\section{INTRODUCTION}

$\mathrm{T}_{\mathrm{t}}$ ransactional Analysis (TA) was discovered by the psychiatrist and psychoanalyst Eric Berne during 1950s. TA is a psychological analysis method that focuses on social transactions and analysis of relationships amongst individuals. It is an effective method to increase communication effectiveness. It is based on the assumption that we make current decisions based on past observations or actions taken that were at one time appropriate to to fulfil the needs but that may no longer be working now. The theory outlines the development \& handling of ourselves, how we relate and interact with others and offer suggestions and involvements which will enable us to change and develop. A psychoanalytic theory of psychology developed by psychiatrist Eric Berne in the late 1950's and is very useful for:
- Analysing interactions with others

- Improving communication effectiveness with others

- Psychotherapy

TA concepts provide a flexible and creative approach to understanding how people function and to the relationships between human behavior, learning and education. Role of TA in education is both preventive and restorative. The aim is to increase personal autonomy, to support people in developing their own personal and professional philosophies and to enable optimum psychological health and growth. The key philosophical concepts that underpin Educational TA are: Effective educators offer empathic acceptance of all human beings as people together with respect for their dignity. These qualities are at the heart of successful learning relationships. 


\section{Role of teachers:}

Teachers play a vital and multi-layered role in setting the direction for educational Institutes that are positive and productive place for colleagues, director, parents and vibrant learning environments for youth, but prevailing knowledge on the best ways to develop these effective leaders is insufficient. There are three types of people, firstly, those who make things happen, and secondly, those who watch things happen, thirdly, those who wonder what has happened. The first category is our main concern. Teachers are the integral part of the Institutes. They are the motivating force behind the well-functioning of institutes. The quality of education also depends on them. If they don't work appropriately the school loses its name. It is true that effectiveness of faculty depends upon their interpersonal communication style. An effective faculty should be balanced the entire six functionsnurturing, regulating, managing tasks, adaptive, creative and confronting. Hence this paper emphasizes transactional functions of college faculty.

\section{Backdrop of the present research}

- TA applicable to human expansion

- Theory of personality

- Based on cognitive ideas

- Interactions

- All above mentioned are significant aspects for teachers.

\section{Objectives of Study:}

(1) To find the Transactional Analysis profiles of faculty members.

(2) To find out whether there is any difference between the Transactional Analysis Styles of faculty members with regard to the following:
A) Gender
B) Age
C) Qualification
D) Organization
E) Position
F) Work Experience
3. To prepare Norms (Transactional Analysis Styles) for the faculty members.

Design/ Methodology/Approach: In the present study, sample consisted of faculty members working for colleges like Management and Engineering, faculty members (Male \& Female) working in different work positions with varied work experience and educational qualification are selected for the study. The sample size for the study is 150 faculty members. The faculty members are of minimum 25 years of age; who are at least Post Graduates and have at least 0-5year of work experience. Various Colleges were approached in Delhi and NCR.

\section{Tool used:}

The inventory used for the study was Transactional Styles Inventory- Teachers (TSI- Te).

- It was developed by Udai Pareek (2003). Test and Re-test method was carried out to establishing reliability of the inventory. The reliability was 0.81 . Styles include:

- Nurturing

- Regulating

- Task- Oriented

- Confronting

- Adaptive

- Creative 
Table 1 depicting the Description of Demographic Variables

\begin{tabular}{|c|c|c|}
\hline Demographic Variables & Number & Percentage \\
\hline \multicolumn{3}{|l|}{ Gender } \\
\hline Male & 45 & 30 \\
\hline Female & 105 & 70 \\
\hline Total & 150 & \\
\hline \multicolumn{3}{|c|}{ Age } \\
\hline $25-35$ & 38 & 25.33 \\
\hline $35-45$ & 87 & 58 \\
\hline $45 \&$ Above & 25 & 16.67 \\
\hline Total & 150 & \\
\hline \multicolumn{3}{|c|}{ Education Qualification } \\
\hline Post Graduates & 32 & 21.33 \\
\hline Post Graduates with UGC NET & 93 & 62 \\
\hline Ph.D & 25 & 16.33 \\
\hline Total & 150 & \\
\hline \multicolumn{3}{|c|}{ College } \\
\hline Engineering & 47 & 31.33 \\
\hline Management & 103 & 68.67 \\
\hline Total & 150 & \\
\hline \multicolumn{3}{|c|}{ Position } \\
\hline Asst. Professor & 128 & 85.33 \\
\hline Associate Professor & 12 & 8 \\
\hline Professor & 10 & 6.67 \\
\hline Total & 150 & \\
\hline \multicolumn{3}{|c|}{ Work Experience } \\
\hline $0-5$ years & 65 & 43.33 \\
\hline 5-10 years & 62 & 41.33 \\
\hline 10 years above & 23 & 15.33 \\
\hline Total & 150 & \\
\hline
\end{tabular}


- Originality/Value: The researchers have created an original database with the help of 150 teaching fraternity in higher education institutes of Delhi, NCR. The researchers have conducted an original study that has attained a workable and truthful conclusion. $\mathrm{T}$ test and Anova has been used for the variables i.e. Nurturing, Regulating, TaskOriented, Confronting, Adaptive and Creative styles in relation the demographic variables under study as statistical analysis to reach to the conclusion and inferences

\section{Results and Findings:}

The results based on various demographical variables are as below:

\section{Gender}

AHo: There is not any significant difference in the transactional analysis of male and female faculty members.

Table 2

\begin{tabular}{|l|l|l|l|}
\hline S.N. & Variables & $\begin{array}{l}\text { T test } \\
\text { Sig }\end{array}$ & Remarks \\
\hline 1 & Nurturing & 0.19 & $\begin{array}{l}\text { Insignificant } \\
\text { There is no significant difference in the mean score of male } \\
\text { and female. }\end{array}$ \\
\hline 2 & Regulating & 0.55 & $\begin{array}{l}\text { Insignificant } \\
\text { There is no significant difference in the mean score of male } \\
\text { and female. }\end{array}$ \\
\hline 3 & Task Oriented & 0.65 & $\begin{array}{l}\text { Insignificant } \\
\text { There is nosignificant difference in the mean score of male } \\
\text { and female. }\end{array}$ \\
\hline 4 & Confronting & 0.29 & $\begin{array}{l}\text { Insignificant } \\
\text { There is no significant difference in the mean score of male } \\
\text { and female. }\end{array}$ \\
\hline 5 & Adaptive & 0.57 & $\begin{array}{l}\text { Insignificant } \\
\text { There is no significant difference in the mean sconf male } \\
\text { and female. }\end{array}$ \\
\hline 6 & Creative & 0.03 & $\begin{array}{l}\text { Significant } \\
\text { Male faculty members are more creative than female faculty } \\
\text { members }\end{array}$ \\
\hline
\end{tabular}


Interpretation: It means our null hypothesis is rejected and alternative hypothesis is accepted. There is a significant difference in the Transactional Analysis Styles of different types of teachers with regard to Gender. The preceding information indicates that male faculty had higher Mean Scores on Creative Style. This implies that a large majority of males are creative while in teaching.

\section{Age}

B Ho: There is no significant difference in the Transactional Analysis Styles of different types of Faculty.

Table 3

\begin{tabular}{|l|l|l|l|}
\hline S.N. & Variables & $\begin{array}{l}\text { T test } \\
\text { Sig }\end{array}$ & Remarks \\
\hline 1 & Nurturing & 0.46 & $\begin{array}{l}\text { Insignificant } \\
\text { There is no significant difference in the mean scores of the } \\
\text { faculty among the three age groups.. }\end{array}$ \\
\hline 2 & Regulating & 0.23 & $\begin{array}{l}\text { Insignificant } \\
\text { There is no significant difference in the mean scores of the } \\
\text { faculty among the three age groups. }\end{array}$ \\
\hline 3 & Task Oriented & 0.37 & $\begin{array}{l}\text { Insignificant } \\
\text { There is no significant difference in the mean scores of the } \\
\text { faculty among the three age groups.. }\end{array}$ \\
\hline 5 & Confronting & 0.43 & $\begin{array}{l}\text { Insignificant } \\
\text { There is no significant difference in the mean scores of the } \\
\text { faculty among the three age groups.. }\end{array}$ \\
\hline 6 & Adaptive & 0.03 & $\begin{array}{l}\text { Significant } \\
\text { Teachers in the age group (45 yrs and above) are significantly } \\
\text { higher on 'Adaptive"' as compared to Teachers in the age } \\
\text { group (25-35 yrs). }\end{array}$ \\
\hline & Creative & 0.18 & $\begin{array}{l}\text { Insignificant } \\
\text { There is no significant difference in the mean scores of the } \\
\text { faculty among the three age groups }\end{array}$ \\
\hline
\end{tabular}

Interpretation: It means our null hypothesis gets rejected and alternative hypothesis is accepted. There is a significant difference in the Transactional Analysis Styles of different Types of teachers with regard to age. The preceding information indicates that Teachers in the age group (45 years and above) are significantly higher on 'Adaptive"' as compared to Teachers in the age group (25-35 years).

\section{Qualification}

C Ho: There is no significant difference in the Transactional Analysis Styles of different types of Faculty with respect to different levels of qualification 


\section{Table 4}

\begin{tabular}{|l|l|l|l|}
\hline S.N. & Variables & $\begin{array}{l}\text { T test } \\
\text { Sig }\end{array}$ & Remarks \\
\hline 1 & Nurturing & 0.01 & $\begin{array}{l}\text { Significant } \\
\text { Teachers with Phd seem to be more nurturing as compared to } \\
\text { teachers with pg qualification. . }\end{array}$ \\
\hline 2 & Regulating & 0.55 & $\begin{array}{l}\text { Insignificant } \\
\text { There is no significant difference in the mean scores of the } \\
\text { faculty among the three groups of qualification. }\end{array}$ \\
\hline 3 & Task Oriented & 0.32 & $\begin{array}{l}\text { There is no significant difference in the mean scores of the } \\
\text { faculty among the three groups of qualification.. }\end{array}$ \\
\hline 5 & Confronting & 0.35 & $\begin{array}{l}\text { Insignificant } \\
\text { There is no significant difference in the mean scores of the } \\
\text { faculty among the three groups of qualification. }\end{array}$ \\
\hline 6 & Adaptive & 0.23 & $\begin{array}{l}\text { Insignificant } \\
\text { There is no significant difference in the mean scores of the } \\
\text { faculty among the three groups of qualification.. }\end{array}$ \\
\hline & Creative & 0.45 & $\begin{array}{l}\text { Insignificant } \\
\text { There is no significant difference in the mean scores of the } \\
\text { faculty among the three groups of qualification. }\end{array}$ \\
\hline
\end{tabular}

Interpretation: It means our null hypothesis gets rejected and alternative hypothesis is accepted. There is a significant difference in the Transactional Analysis Styles of different Types of teachers with regard to qualification. The preceding information indicates that The teachers with $\mathrm{Ph} d$ seem to be more nurturing as compared to teachers with post graduate qualification.

\section{Organization:}

D Ho: There is no significant difference in the Transactional Analysis Styles of different types teachers in relation to the type of organization

Table 5

\begin{tabular}{|l|l|l|l|}
\hline S.N. & Variables & $\begin{array}{l}\text { T test } \\
\text { Sig }\end{array}$ & Remarks \\
\hline 1 & Nurturing & 0.07 & $\begin{array}{l}\text { Insignificant } \\
\text { There is no significant difference in the mean scores of the } \\
\text { teachers for the two types of organizations. }\end{array}$ \\
\hline 2 & Regulating & 0.38 & $\begin{array}{l}\text { Insignificant } \\
\text { There is no significant difference in the mean scores of the } \\
\text { teachers for the two types of organizations. }\end{array}$ \\
\hline 3 & Task Oriented & 0.25 & $\begin{array}{l}\text { Insignificant } \\
\text { There is no significant difference in the mean scores of the } \\
\text { teachers for the two types of organizations. }\end{array}$ \\
\hline
\end{tabular}




\begin{tabular}{|l|l|l|l|}
\hline 4 & Confronting & 0.14 & $\begin{array}{l}\text { Insignificant } \\
\text { There is no significant difference in the mean scores of the } \\
\text { teachers for the two types of organizations. }\end{array}$ \\
\hline 5 & Adaptive & 0.45 & $\begin{array}{l}\text { Insignificant } \\
\text { There is no significant difference in the mean scores of the } \\
\text { teachers for the two types of organizations. }\end{array}$ \\
\hline 6 & Creative & 0.07 & $\begin{array}{l}\text { Insignificant } \\
\text { There is no significant difference in the mean scores of the } \\
\text { Teachers for the two types of organizations. }\end{array}$ \\
\hline
\end{tabular}

Interpretation: It means our null hypothesis is accepted and alternative hypothesis gets rejected. There is no significant difference in the mean scores of the Teachers for the two types of organizations.

\section{Position/ Designation:}

E Ho: There is no significant difference in the Transactional Analysis Styles of different types of Faculty.

Table 6

\begin{tabular}{|l|l|l|l|}
\hline S.N. & Variables & $\begin{array}{l}\text { T test } \\
\text { Sig }\end{array}$ & Remarks \\
\hline 1 & Nurturing & 0.19 & $\begin{array}{l}\text { Insignificant } \\
\text { There is no significant difference in the mean scores of the } \\
\text { Teachers among the three groups of position.. }\end{array}$ \\
\hline 2 & Regulating & 0.34 & $\begin{array}{l}\text { Insignificant } \\
\text { There is no significant difference in the mean scores of the } \\
\text { Teachers among the three groups of position.. }\end{array}$ \\
\hline 3 & Confronting & 0.04 & $\begin{array}{l}\text { Insignificant } \\
\text { There is no significant difference in the mean scores of the } \\
\text { Teachers among the three groups of position.. }\end{array}$ \\
\hline 4 & 0.55 & $\begin{array}{l}\text { Significant } \\
\text { The faculty at the level of Assistant professors are more } \\
\text { confronting as compared to professors in their transactional } \\
\text { styles }\end{array}$ \\
\hline 5 & Adaptive & 0.43 & $\begin{array}{l}\text { Insignificant } \\
\text { There is no significant difference in the mean scores of the } \\
\text { Teachers among the three groups of position.. }\end{array}$ \\
\hline 6 & Creative & 0.11 & $\begin{array}{l}\text { Insignificant } \\
\text { There is no significant difference in the mean scores of the } \\
\text { Teachers among the three groups of position.. }\end{array}$ \\
\hline
\end{tabular}


Interpretation: It means our null hypothesis is rejected and alternative hypothesis is accepted. There is a significant difference in the Transactional Analysis Styles of different Types of teachers with regard to their position as a faculty. The preceding information indicates that the faculty at the level of Assistant professors are more confronting as compared to professors in their transactional styles.

\section{ANOVA Test Results:}

For Age: Table 7

\begin{tabular}{|l|l|l|l|l|l|}
\hline & $\begin{array}{l}\text { Sum of } \\
\text { Squares }\end{array}$ & Df & Mean Squares & F & $\begin{array}{l}\text { Sig. } \\
\text { value }\end{array}$ \\
\hline Between Groups & 1599.1 & 2 & 799.55 & 193.59 & .04 \\
\hline Within Groups & 607.145 & 147 & 4.13 & & \\
\hline Total & 2206.24 & 149 & & & \\
\hline
\end{tabular}

For Educational Qualification: Table 8

\begin{tabular}{|l|l|l|l|l|l|}
\hline & $\begin{array}{l}\text { Sum of } \\
\text { Squares }\end{array}$ & Df & Mean Squares & F & $\begin{array}{l}\text { Sig. } \\
\text { value }\end{array}$ \\
\hline Between Groups & 526.78 & 2 & 263.39 & 196.26 & 0.26 \\
\hline Within Groups & 197.57 & 147 & 1.34 & & \\
\hline Total & 724.35 & 149 & & & \\
\hline
\end{tabular}

For position: Table 9

\begin{tabular}{|l|l|l|l|l|l|}
\hline & $\begin{array}{l}\text { Sum of } \\
\text { Squares }\end{array}$ & Df & Mean Squares & F & $\begin{array}{l}\text { Sig. } \\
\text { value }\end{array}$ \\
\hline Between Groups & 983.56 & 2 & 491.78 & 117.09 & 0.00 \\
\hline Within Groups & 617.89 & 147 & 4.20 & & \\
\hline Total & 1601.45 & 149 & & & \\
\hline
\end{tabular}

For Work Experience: Table 10

\begin{tabular}{|l|l|l|l|l|l|}
\hline & $\begin{array}{l}\text { Sum of } \\
\text { Squares }\end{array}$ & Df & Mean Squares & F & $\begin{array}{l}\text { Sig. } \\
\text { value }\end{array}$ \\
\hline Between Groups & 835.57 & 2 & 417.57 & 252.72 & .63 \\
\hline Within Groups & 242.21 & 147 & 1.65 & & \\
\cline { 1 - 4 } Total & 1077.78 & 149 & & & \\
\hline
\end{tabular}




\section{CONCLUSION}

The major findings and results of the study indicate that faculty development programs need to be promoted and implemented by organizations to improve the TA styles of their faculty for better job performance. These training modules can be customized to every organization so as to meet their needs. From the data obtained, it has been observed that faculty development programs need to be conducted for male faculty to be more supportive, compassionate, understanding and helpful towards their peers and subordinates. Supportive style will help them to be more sensitive and caring towards their peers \& subordinates which will help in maintaining a friendly atmosphere in the working place.

Faculty in the age group (20-30 years) has to be trained to be more patient and resilient. Their nature of being aggressive has to be focused in the right direction for positive results. They can experiment and implement new ideas but not before conforming their validity and usage. Due to lack of higher qualification, graduates feel the pressure to prove them. Faculty can be trained to be more resilient. They can implement their creative ideas in a positive way but with patience. They have to be taught problem solving skills so that they can help their students \& peers. Faculty has to be trained to be more supportive and considerate towards their students. They need to focus more on the job allotted than experimenting all the time. According to Mishra (2010), faculty with higher work experience scored significantly higher on EI scale compared to less experienced faculty. Faculty with less or little work experience have to be given training so that they get to know more about their organization and its working culture. This will in turn help them to work more efficiently and relate to their seniors and peers better. They need to be taught resiliency and problem-solving skills so that they perform better.

\section{REFERENCES}

1) Argyris, C. (1957). The Individual and Organization: Some Problems of Mutual Adjustment, Administrative Quarterly

2) Atri Sengupta.,Vijai, N.\& Giri .(2009). Alexithymia and Managerial Styles: Implications in Indian Organizations. Journal of the Indian Academy of Applied Psychology, 35, 71-77.

3) Chirayath (2008). Transactional Styles and Gender a Co-relational Study. Management and Labour Studies, 33(2), 175-193

4) Dr. Arindam Chatterjee (2012.An Empirical Analysis of Interpersonal Styles with Special Reference to Employees in Public Sector Banks. International Journal of Applied Research \& Studies, 1(3),1- 13

5) Dr. Navpreet Singh Sidhu (2012).A Study of the Managerial Styles of Executives in the Manufacturing Companies of Punjab. International Journal of Research in Commerce, IT\& Management, 2(11), 105- 111

6) Dr. Sanjeev Kumar (2013).Principals' Managerial Styles \&Their Effect on Institutional Effectiveness. International Research Mirror,3133

7) Dr. Surabhi Purohit (2013).Relationship between Principals' Leadership Style and Teaching Style of Teachers. International Journal of Research in Commerce, Economics \& Management, 3(9), 4852

8) Indu Khetarpal \& Srivastava, R.C. (2000).Management styles grounded in interpersonal roles: focus on heads of school in India, International Journal of Educational Management. International Journal of Educational Management, 14 (2), 74 - 83

9) Kamal Jeet Sandhu \& Nidhi Gurbaxani (2013). Life Satisfaction and Role Efficacy as Predictors of Transactional Styles. Psychological Thought, 6(2), 326-338

10) Panigrahy Abani Kumar \& Mangaraj Sujata (2011). Transactional styles inventory: a behavioral instrument for training need assessment of B-school teachers. A Journal of 
Decision Making,11 (2),105-115

11) U.S. Army Handbook (1973). Military Leadership

12) Vaz, I.T. (1988). "Women Managers in Banking Sector", Indian Management, 14-18.

13) Vroom, V.H. (1960). Some Personality Determinants of the Effects of Participation, New Jersey: Englewood Cliffs.

14) Weisner, J. (1995). Raising Assertiveness in Youth. Youth Update Newsletter, Research Press. 